\title{
COMMENTS
}

\section{The Rights of Prisoners to Medical Care and the Implications For Drug-Dependent Prisoners and Pre- trial Detainees}

In recent years, there has been a growing sensitivity to the medical needs of prisoners and pretrial detainees. ${ }^{1}$ The common law right ${ }^{2}$ to in-prison medical care has been codified in, and at times broadened by, state legislation. ${ }^{3}$ Federal legislation designed to guard the prisoner's medical well-being has been enacted. ${ }^{4}$ And, perhaps most importantly, the notion of a constitutional right to inprison medical care, arising out of the eighth amendment's prohibition of cruel and unusual punishment and the fourteenth amendment's guarantee of due process, has shown renewed promise of providing significant protection. ${ }^{5}$

At the same time, there has also been a developing awareness that new solutions to the problem of drug addiction are needed. Many observers today believe that it is unnecessary to subject an addict to the painful process of an abrupt, "cold turkey" withdrawal in order to cure his physiological dependency, ${ }^{6}$ when the same result can be achieved with relatively little pain ${ }^{7}$ through the use of methadone, a synthetic narcotic, administered in gradually decreasing doses. This treatment is known as short-term detoxification.

' Yet surveys of local jails indicated that in 1970,49 percent of the 3300 jails surveyed had no medical facilities whatsoever, and, in $1972,65.5$ percent had only first aid facilities. R. Goldfarb, Jails: The Ultimate Ghetto 83, 86 (1975).

2 See text and notes at notes 9-11 infra.

3 See text and notes at notes 12-27 infra.

- See text and notes at notes 28-39 infra.

5 See text and notes at notes 40-78 infra. For an exhaustive list of cases concerning the issue of medical aid for prisoners, see ABA Resource Center on Correctional Law and Legal Services, Prisoners' Legal Rights: A Bibliography of Cases and Articles, PRI. L. REP. 18 (Spec. ed. 1974). See generally, R. GoldFarb, supra note 1; H. KerPER \& J. KERPER, LEGaL RIGHTS of the Convicted 433 (1974); South Carolina Department of Corrections, The Emerging Rights of the Convicted (W. S. McAninch \& E. D. Wedlock, eds.) (1972) [hereinafter cited as The Emerging Rights]; Sneidman, Prisoners and Medical Treatment: Their Rights \& Remedies, 4 Crim. L. Bul. 450 (1968); Zalman, Prisoners' Right to Medical Care, 63 J. CRIM. L., Criminology \& Pouice Sci. 185 (1972); Comment, Beyond the Ken of the Courts: A Critique of Judicial Refusal to Review the Complaints of Convicts, 72 YALE L.J. 506 (1963).

- See text and notes at notes 94-95 infra.

'See text and notes at notes 96-103 infra. 
Methadone may also be used as a long-term narcotic surrogate which, when combined with a variety of social services, apparently produces a less physically and socially destructive dependency than the use of illegally purchased heroin. ${ }^{8}$

The important issue raised by these contemporaneous developments is whether a drug-dependent prisoner or pretrial detainee can demand either form of methadone treatment under the common law, state or federal statutes, or the United States Constitution. This comment first examines the various non-constitutional rights to medical care, both in general and in their application to drugdependent prisoners. The constitutional right to medical care is then examined and the two standards used by the federal courts to define this right-one restrictive and one more protective of prisioner's rights - are explained. It is then suggested that narcotics addiction is a disease requiring medical treatment and that shortterm methadone detoxification is the generally accepted medical "cure." Finally, the comment applies the two constitutional standards to the disease of addiction in order to determine if, under either rubric, the drug-dependent prisoner or pretrial detainee is entitled to short-term methadone detoxification or to long-term methadone maintenance.

\section{The Prisoner's Non-Constitutional Rights to Medical Care and Drug Treatment}

\section{A. Common Law Rights}

State courts have long recognized that prison authorities have a common law duty to provide in-prison medical care, on the theory that "[i]t is but just that the public be required to care for the prisoner, who cannot, by reason of the deprivation of his liberty, care for himself." 9 A prisoner who has been injured by the negligence of a prison official or the medical malpractice of a prison physician has a common law tort action based on a breach of that duty. ${ }^{10}$ For

${ }^{8}$ See text and notes at notes 104-111 infra.

- Spicer v. Williamson, 191 N.C. 487, 490, 132 S.E. 291, 293 (1926).

${ }^{10}$ See, e.g., Irwin v. State, 117 Ga. App. 1, 159 S.E.2d 719, 723 (1967); Hight v. New York, 35 Misc.2d 926, 231 N.Y.S.2d 361 (Ct. Cl. 1962) (inmate, confined to prison hospital, received $\$ 15,000$ as compensation for negligence of prison hospital employees). Some states immunize the prison warden from tort liability on the theory that he acts in a quasi-judicial capacity. See United States v. Muniz, 374 U.S. 150, 163 (1963) (listing cases). Federal courts, in dismissing eighth amendment claims, often note that the plaintiff's proper action is a state law tort claim. See, e.g., Nettles v. Rundles, 453 F.2d 889 (3d Cir. 1971). 
the drug-dependent prisoner desiring methadone detoxification, however, the negligence action appears to offer little hope for relief: unless the use of methadone becomes so generally accepted that its denial to an addict constitutes per se malpractice, it would be difficult to show negligence in the conscious decision not to provide short-term detoxification. ${ }^{11}$

\section{B. Statutory Rights to Medical Care}

1. State Statutes. Most states have enacted legislation defining the general standard of medical care to be provided in the state's prisons and jails. A few statutes also define the specific treatment to be provided drug-dependent prisoners. Yet broad, imprecise language, coupled with a paucity of reported judicial interpretation, often makes it difficult to ascertain the scope and effectiveness of these provisions.

The prisoner's right to general medical care is defined in various ways. Nearly twenty states simply require a supervisory prison official to provide medical and health services. ${ }^{12}$ Other state statutes impose narrower and more specific duties on prison officials: a duty to examine each prisoner on entrance to the jail or prison; $;^{13}$ a duty to provide special treatment, including isolation, for prisoners with communicable diseases $;{ }^{14}$ or a duty to transfer a prisoner to another

"A related problem is that the value of the negligence action seems limited because the sole available remedy is compensatory. Although money damages will lie for injury caused by negligent care, injunctive relief is not available because negligent care, by its very nature, cannot be anticipated. Furthermore, since abrupt withdrawal causes only temporary, albeit severe pain, a prisoner would be unable to show that he would be irreparably harmed by the choice of abrupt withdrawal as treatment. Yet the lack of an injunctive remedy would probably have at most a minor impact on the drug-dependent prisoner's medical well-being. The prison authorities would undoubtedly prescribe a detoxificant voluntarily if they knew that the prisoner would be entitled to compensation in the event they failed to do so.

${ }_{12}$ See, e.g., Del. Const. art. $1, \S 11$; Ala. Code tit. 45, § 125 (1958); Alaska Stat. ch. 33, $\$ 30.050$ (Supp. 1974); ArIz. Rev. Stat. ANN. ch. 31, $\$ 201.01$ (Supp. 1974); D.C. Code ENCYCL. ANn. ch. 24, $\$ 442$ (1967); Ga. Code Ann. ch. 77, $\$ 309$ (e) (1973); IdAho Code ch. 20, $\S 209$ (Supp. 1973); Ill. Rev. Stat. ch. 38, $\$ 103-2$ (1973); IND. ANn. Stat. tit. 11, $\$ \S 1-1.1-$ 21.9, 1-1.1-30.5 (Burns 1973); Iowa Code ANN. § 338.1 (1973); Miss. Code ANN. ch. 47, § 1-57 (1972); Mo. Ann. Stat. tit. 13, § 221.120 (Vernon 1962); Neb. Rev. Stat. ch. 83,8181 (1971); N.H. Rev. Stat. AnN. § 619-9 (1955); N.M. Stat. AnN. ch. 42, \$ 2-4 (1972); Tenn. Code Ann. ch. 41, §§ 1115, 1226 (1955); UTAH Code ANN. ch. 64, §§ 9-13, 9-19, 9-20 (1961); Wyo. Stat. ANN. $\$ 18-299$ (1959).

is See, e.g., Hawail Rev. Stat. \& 353-10 (1968); Mass. Ann. Laws ch. 127, § 16 (1972); Pa. Stat. Ann. tit. 61, § 632 (Supp. 1974); R.I. Gen. Laws AnN. § 13-3-1 (Supp. 1973); S.D. Compiled Laws Ann. ch. 24, $\$ 2-4$ (1967); Wash. Ad. Code $\$ 275-92-030$ (1973).

"See, e.g., Conn. Gen. Stat. Ann. ch. 19, $\$ 60$ (1958); Mich. Stat. Ann. ch. 14, $\$ 84$ (1969); TENn. Code ANN. ch. 41, § 318 (1955); UTAH COdE ANN. ch. 64, § 9-53 (1961); VA. Code ANN. $\S \S 32-81,32-82$ (1973) (penitentiaries, jails). 


\section{facility if the available treatment is inadequate..$^{15}$}

The standards of care imposed by these general statutes are usually vague; thus, in over two-thirds of the states, authority is delegated to either a state administrative agency or a state court to promulgate more thorough regulations. ${ }^{16}$ Some regulations ${ }^{17}$ are as broad and imprecise as the statutes themselves, using terms such as "commensurate with good medical practice" to define the general level of prison medical care. ${ }^{18}$ Others are more specific, defining, for example, when care is to be available, ${ }^{19}$ the circumstances under

${ }^{15}$ See, e.g., Ga. Code AnN. ch. 77, § 309 (1973); Ind. Ann. STat. ch. 12, § 5-1-5 (Burns 1973); Kan. Stat. AnN. ch. 75, § 5249 (Supp. 1973); Md. ANn. Code art. 27, § 698 (1957); Mass. ANn. Laws ch. 127, § 90A (Supp. 1973); N.H. Rev. Stat. AnN. § 623-1 (1955); N.J. Stat. Ann. ch. 30, § 4-7 (1964); VA. Code ANN. § 53-185 (1973); W. VA. Code AnN. \& 25-1-16 (Supp. 1974).

16 See, e.g., Alaska Stat. ch. 33, $\$ 30.030$ (Supp. 1974); Cal. Penal Code $\$ 5058$ (West 1970); Conn. Gen. Stat. Ann. ch. 18, § 81 (Supp. 1974); Del. Code Ann. tit. 11, $\$ 6517$ (1975); D.C. Code Encycl. ANn. ch. 24, § 945.21 (1967); Fla. Stat. ANn. ch. 46, § 945.21 (1963); Ga. Code Ann. ch. 77, § 307 (1973); Hawain Rev. Stat. § 353-3 (1968); Idaho Code tit. 20, § 212 (1948); IlL. Rev. Stat. ch. 38, § 1003-7-1 (1973); Iowa Code ANn. \& 218.4 (1973); Kan. Stat. ANN. ch. 76, $\S \S 5251,5256$ (Supp. 1974); Ky. REv. STAT. ANN. ch. $361, \S 3$ and ch. 513, $\S 274$ (1974); La. Rev. Stat. AnN. ch. 15, $\S \S 702,709,854$ (West Supp. 1974); ME. Rev. Stat. AnN. tit. 34, $\$ 7$ (1964); Mo. AnN. CodE art. 27, $\$ 676$ (1957); Mass. AnN. Laws ch. 124, $\$ 1$ (Supp. 1973); Mich. Stat. AnN. ch. 14, § 791.206 (1969); Mo. Ann. StaT. tit. 13, § 216.020(6) (Vernon 1962); N.H. Rev. Stat. ANN. § 622.5 (1955); N.M. Stat. Ann. ch. 42, § 1-1.1 (1972); N.Y. Correc. Law $\S 112$ (McKinney Supp. 1974); N.C. Gen. Stat. ch. 148, $\$ 11$ (Supp. 1974); N.D. Cent. Code $\$ 12-44-04$ (1960); Ohio Rev. Code AnN. $\$ 302.203$ (Page Supp. 1974); Okza. Stat. AnN. tit. 57, § 42 (1969); ORe. Rev. Stat. § 421.016 (1972); Pa. Stat. ANN. tit. 71, § 1473 (Supp. 1974); R.I. GEN. Laws ANN. § 13-1-2 (1970); S.C. CoDE ANN. \$§ 55-303, 55-383 (1962); S.D. Compiled Laws ANn. ch. 24, § 1-15-20 (1967); UtAH Code ANN. ch. 64, § 9-2 (1961); VT. Stat. Ann. tit. 28, \$§ 101, 102 (Supp. 1974); VA. Code ANN. tit. 53, \& 23 (1974); Wash. Rev. Code ANn. § 72.13.170 (1962); WIs. STAT. ANN. §§ 52.04, 53.02, 53.07 (Supp. 1974) (as interpreted by 46 Op. Wis. ATT'y Gen. 280 (1957)).

${ }^{17}$ The following discussion is based on information obtained in response to inquiries sent to the fifty state departments of corrections. Twenty-four responses were received.

is See, e.g., Arizona Dep't of Corrections, Proposed Manual of Medical Corr'L Stands. ๆ 1, 2; Cal. Dep'T of Corrections, Rules and Regulations of the Director ch. 4, art. 7 (1974) (reasonable care); Georgia Dep'T of CoRrections, RUtes AND REg. $\$ 125-2-9-.01$ (1974) (needed medical or hospital care); Corrections Division, Hawail Dep'T of Social Services \& Housing, Health \& Medical Services in the Corrections Division (1972) (adequate health and medical services); ILlinors DEP'T OF CORRECTIONS, AD. REG. § 836; KANSAS Dep't of Corrections \& Institutions, Kansas Ad. Procedure No. 130, Standards for Health Care in Dep't of Corrections \& Institutions (proper and adequate care); Maryland Dep't of Public Safety \& Correctional Services, Division of Corrections Reg. No. 130-2 (1974); Michigan Dep't of Corrections, Policy Directive No. R-3 (1973) (health care consistent with prevailing standards for non-prison institutional settings); DIvISION OF CORRECTIONS \& Parole, New Jersey Dep't of Institutions \& Agencies, Medical Services Standards \$ 310.211 (1970) and $\S 310.271$ (1968) (at least minimally accepted medical standards); NoRTH Dakota State Penitentiary, Rights and Responsibilities of Prisoners No. 4 (right to medical treatment); South Carolina Dep't of Corrections, Polictes and Procedures Manual $\S$ 400.20 (best medical care and treatment under existing circumstances).

19 See, e.g., Arizona Dep't of Corrections, Proposed Manual of Medical Correctional 
which a prisoner is to be transferred to another facility to receive better care, ${ }^{20}$ and the extent to which a prisoner may be treated by his personal physician. ${ }^{21}$ Yet, on the whole, the coverage of such regulations is scanty. Despite the existence of appropriate statutory authority, state-wide regulations have not been promulgated at all in a few states, and thus each prison facility is free to establish its own standards..$^{22}$ More significantly, the regulations that have been promulgated apparently apply only to state prisons, with local jails left free to establish their own regulations.

In addition to the problems of imprecise language and incomplete coverage, the state regulatory schemes leave certain other questions unanswered. First, the statutes are generally silent on the issue of enforcement: it is unclear whether a prisoner may sue to compel compliance with the statutes or regulations, or whether his sole right of action is a common law tort action. If, as has been suggested, ${ }^{23}$ the statutes are simply codifications of common law principles, then their purpose would be to clarify the relevant standard of care in a tort action, rather than to create a novel right of action.

Second, the implications of the general statutes insofar as the drug-dependent prisoner seeking short-term methadone detoxification is concerned are unclear. Most statutes do not mention either addiction or withdrawal specifically and, although the available evidence is scanty, it is doubtful that a state court would infer a

Stands. If 9, 10; Conn. Dep't of Corrections, Minimum Standards for Treatment of Offenders $\$ \S 22$ (1), 25 (1974); Georgia Dep'T of Corrections, Rules and Regs. $\$ \S 125-2-9$ .02, 125-2-9-.03, 125-2-9.04 (1974); Corrections Drvision Hawail Dep't of Social Services \& Housing, Health \& Medical Services in the Corrections Division (1972); Illinois Dep'T of Corrections, Ad. Reg. § 836; Division of Corrections \& Parole, New Jersey Dep't of Institutions \& Agencies, Medical Services Standards $\$ 310.223$ (1968); Bureau of Corrections, Pennsyluania Dep't of Justice Medical Protocol, Ad. Directive No. BC-ADM 820; South Carolina Dep't of Corrections, Policies and Procedures Manual $\S 400.20(2)(\mathrm{g})$.

${ }^{20}$ See, e.g., Arizona Dep't of Corrections, Proposed Manual of Medical Correctional Standards $7 \uparrow$ 15, 24; Conn. Dep't of Corrections, Minimum Standards for Treatment of Offenders \$ 22(2) (1974); Illinois Dep't of Corrections, AD. Reg. § 821; Wyoming Prison Reg. No. E(1); $f$. Division of Corrections, Florida Dep't of Health \& Rehabilitation Services, Contractual Terms Governing Transfer of Inmates for Medical Treatment.

${ }^{21}$ See, e.g., Illinois Dep'T of CorRections, AD. REG. $\$ \S 836,862$ (treatment may be prescribed only by the prison physician; no absolute right to treatment prescribed by private physician); South Carolina Dep't of Corrections, Policies \& Procedures Manual $\$ 400.20$; cf. Division of Corrections \& Parole, New Jersey Dep't of Institutions \& Agencies, MediCAL SERvices STANDARDS $\$ 310.277$ (1971) (treatment may be prescribed only by prison physician, with exception of first aid).

${ }^{22}$ Oregon (letter of E. W. Heidenreich, Exec. Ass't, Corrections Division, Dep't of Human Resources, March 4, 1975); Wisconsin (letter of R. McCauley, Acting Administrator, Division of Corrections, Dep't of Health \& Social Services, Feb. 12, 1975).

2 Anderson v. Nosser, 438 F.2d 183, 194 (5th Cir. 1971). 
right to methadone from the general statutory right to medical care. In one of the few cases on this point, a California court construed a statute requiring prison authorities to provide "aid as necessary to ease any symptoms of withdrawal" 24 as entitling the prisoner only to valium, a tranquilizer, instead of methadone, even though methadone detoxification is the more effective treatment. ${ }^{25}$

Like California, a handful of states have enacted legislation expressly mandating special treatment for the drug-dependent prisoner. Washington, for example, requires that habitual narcotics users-and, by implication, methadone-maintained prisoners-be treated until cured..$^{26}$ The statute does not specifically indicate, however, what treatment is to be provided. Maryland and Pennsylvania have recently enacted legislation that expressly makes detoxification mandatory in all state prisons and jails. ${ }^{27}$ Although the Pennsylvania statute does not specify the method of detoxification to be used, the Maryland statute requires that methadone be the prescribed treatment, a requirement that may prove unfortunate if a more effective treatment is discovered.

In sum, while the state statutes and regulations provide the prisoner with a significant degree of protection, on the whole they are plagued with several deficiences. The standards of care they purport to establish are vague and the mode of private enforcement of those standards is ambiguous. Perhaps more important, however, is the inadequancy of the coverage and often of the medical care itself under these provisions: local prisons and jails are generally not regulated at all and, even where state regulations do apply, the quality and type of medical treatment mandated may vary significantly from state to state. Thus, to ensure satisfaction of their medical needs, prisoners may have to look beyond the state statutes to

24 Cal. Health \& Safety Code $\$ 11222$ (West Supp. 1974).

${ }^{25}$ In re Robert Freeman, No. HC 1537 (San Diego Super. Ct. 1970), discussed in Goldin, Methadone Detoxification, A Non-Controversial Solution to In-Custody Narcotic Withdrawal, 47 CAL. B.J. 14 (1972). At the time of the Freeman case, the provisions of section 11222 of the Cal. HEALTH \& SAFETY CODE were contained in section 11396. See text and notes at notes $96-103$ infra.

${ }^{26}$ WASH. REv. CODE $\$ 69.32 .090$ (1962):

... [A]ny person who shall be confined or imprisoned in any state, county, or city prison in the state and who may be reasonably suspected by the health officer of being a narcotic addict shall be examined for and if found to be an habitual user of said drug or any of them, shall be treated therefor at public expense . . . .

Coerced medical treatment may raise difficult constitutional issues. See generally, Opton, Psychiatric Violence Against Prisoners: When Therapy Is Punishment? 45 Miss. L. Rev. 605 (1974); The EMERGing RIGHTS, supra note 5, at 153-54.

${ }^{27} \mathrm{MD}$. ANn. CoDE art. 27, § 700F (Supp. 1974); Drug and Alcohol Abuse Control Act $\S$ 6(a), Pa. Stat. Ann. tit. 71, § 1690.106 (Supp. 1974). 
constitutionally based guarantees.

2. Federal Statutes. Several federal statutes concern the right of prisoners to medical care. Under section 4042 of title 18 of the United States Code, the Bureau of Prisons is required to "provide suitable quarters for the safekeeping, care, and subsistence" of all federal prisoners. ${ }^{28}$ Section 4042 does not, however, create a private cause of action in favor of a person who suffers damage due to a failure of the Bureau or its officers or employees to carry out the commands of the statute. ${ }^{29}$ Thus, the federal prisoner must rely on the deprivation of another statutory, common law, or constitutional right as a basis of relief.

Under the Federal Tort Claims Act, ${ }^{30}$ a federal prisoner is entitled to sue the United States Government to remedy injuries caused by the negligence of a government employee. ${ }^{31}$ There are, however, major qualifications on the government's liability: it is not liable for an act or omission of a government employee "in execution of a statute or regulation, whether or not such statute or regulation be valid"; nor is it liable for the "exercise or performance or failure to exercise or perform a discretionary function" by an agent "whether or not the discretion involved be abused"; ${ }^{22}$ nor is it generally liable for the intentional torts of its employees. ${ }^{33}$

The Federal Tort Claims Act protects the prisoner's right to medical care to the extent that it permits compensation for the negligent acts of federal government employees. Therefore, it would not create a right to methadone detoxification unless that treatment were to become so well established that the failure to prescribe it would constitute medical malpractice. Yet, even then, as long as the decision to withhold methadone treatment was a deliberate one, the prisoner might not have an actionable claim because of the intentional tort exception.

Beyond these general provisions, the federal prisoner may look

${ }^{28} 18$ U.S.C. $\$ 4042$ (1970).

29 Brown v. United States, 342 F. Supp. 987, 992 (S.D. Ark. 1972). Although a suit to remedy a breach of section 4042 may be brought under the Federal Tort Claims Act, the scope of the duty imposed in fact upon the prison system is unclear. Williams v. United States, 405 F.2d 951 (9th Cir. 1969).

${ }^{30} 28$ U.S.C. $\$ \S 2671-2680$ (1970).

31 United States v. Muniz, 374 U.S. 150 (1963). A prisoner will prevail when a "private individual under like circumstances would be liable under state law." Id. at 153. The immunity from suit which some states extend to those in charge of prisoners does not extend to authorities in federal prisons, since 18 U.S.C. $\S 4042$ (1970) establishes the duty of care owed by the government. Id. at 164-65.

3228 U.S.C. $\$ 2680($ a) (1970). But see K. Davis, Administrative Law Treatise $\S 25.08$, at 471 (1958).

${ }^{33} 28$ U.S.C. $\S 2680(\mathrm{~h})(1970)$. 
to the Narcotics Addict Rehabilitation Act, ${ }^{34}$ which grants federal courts discretionary authority to suspend the prosecution of a person charged with an offense against the United States in order to determine if the defendant is a narcotics addict. ${ }^{35}$ If the court finds that the defendant is an addict and that he is a likely candidate for rehabilitation, it may order him civilly committed for up to thirtysix months of treatment. Upon successful completion of the treatment, the charges must be dropped. The Act provides a similar program of long-term therapeutic civil commitment for addicts who are convicted prisoners as well. ${ }^{36}$

Despite its rehabilitative purpose, the Narcotics Addict Rehabilitation Act provides the drug-dependent federal prisoner with only limited protection. The Act grants broad discretionary powers to the courts to determine whether a given defendant or convict is suitable for rehabilitation; an addict who is deemed unsuitable for rehabilitation will be automatically excluded from special programs. While the Bureau of Prisons has enlarged by regulation the number of addicts eligible for special treatment, ${ }^{37}$ it has also substantially curtailed the potential effectiveness of those programs by restricting the use of methadone, permitted by a 1972 amendment to the Act, ${ }^{38}$ to participants outside the prison confines. ${ }^{39}$ Thus, while an imprisoned addict may be eligible for treatment based on the nature and history of his drug dependence, he will not be entitled to the methadone detoxification he may desperately need.

\section{The Prisoner's Constitutional Right to Medical Care}

In addition to the rights conferred by the common law, statutes, and regulations, a prisoner has a constitutional right to needed medical treatment. Imprisonment is the punishment for crime; when deprivation of needed medical care is added to the imprisonment, the additional suffering it causes constitutes cruel and unusual pun-

34 Narcotic Addict Rehabilitation Act § 101, 28 U.S.C. §§ 2901-2906 (1970).

${ }^{35}$ Defendants charged with certain crimes, such as crimes of violence or drug trafficking, are ineligible to participate in the program. 18 U.S.C. $\$ 2901(\mathrm{~g})(1970)$.

${ }^{38}$ Narcotic Addict Rehabilitation Act $\S 201,18$ U.S.C. $\S \S 4151-55$ (1970).

37 Bureau of Prisons Policy Statement $\$ 8542$ (1973).

${ }_{38}$ Pub. L. No. $92-420$, amending 28 U.S.C. $\$ 2901$ (d), 18 id. $\$ 4251$ (c), and 42 id. $\S$ 3411(b): "Treatment' . . . includes . . . rehabilitative services designed to protect the public and benefit the addict by eliminating his dependence on addicting drugs, or by controlling his dependence, and his susceptibility to addiction." This amendment, by expanding the definition of "treatment" to include "control of dependence" in addition to "elimination of dependence," permits methadone use as an additional mode of treatment. S. REP. No. 921071, 92d Cong., 1st Sess. (1972).

39 Bureau of Prisons Policy Statement $\$ 8651$ (1973). 
ishment in excess of that imposed by the sentencing court. ${ }^{40}$ Thus, the intentional denial of needed treatment violates the cruel and unusual punishment clause of the eighth amendment, ${ }^{41}$ or, if the prisoner is in a state or local jail or prison, the due process clause of the fourteenth amendment. ${ }^{42}$ While this principle is easily stated, the standard of medical care that it imposes is not. Currently, there appear to be two judicial' interpretations of that standard-one widely accepted and the other, which provides the prisoner with more substantial protection, perhaps receiving increased acceptance..$^{43}$

\section{A. The Majority Standard}

Under the majority standard, the prisoner's right to medical treatment is violated only when needed treatment is intentionally withheld by prison officials. ${ }^{4}$ Treatment prescribed or administered with a "callous disregard" for the prisoner's welfare or treatment that is "grossly negligent" is also impermissible because it is considered to be the equivalent of an intentional deprivation of needed care. ${ }^{45}$ There is, however, a broad de minimis qualification to the majority standard: an intentional deprivation is cruel and unusual only when it is extraordinary, shocking, or barbaric. ${ }^{46}$ Under this standard, a prisoner is entitled to "some," but not the best, care, and negligent care is not actionable because it is considered the inevitable consequence of attending to the prisoner's medical needs at all. ${ }^{47}$

to Ramsay v. Ciccone, 310 F. Supp. 600, 605 (W.D. Mo. 1970) (addendum),

"Id.

12 See Robinson v. California, 370 U.S. 660, 667 (1962).

13 Prisoners claiming damages for a breach of the duty to provide medical care generally bring an action pursuant to 42 U.S.C. $\$ 1983$ (1970). A prisoner claiming to be aggrieved by a current or continuing violation is likely to file a petition of habeas corpus. Suits for injunctive relief are rarely brought under these circumstances because of the relatively detailed and lengthy procedures involved. Ramsay v. Ciccone, 310 F. Supp. 600, 605-06 (W. D. Mo. 1970) (addendum).

"Coleman v. Johnson, 247 F.2d 273 (7th Cir. 1957).

is Pinon v. Wisconsin, 368 F. Supp. 608 (E.D. Wis. 1973); Ramsay v. Ciccone, 310 F. Supp. 600 (W.D. Mo. 1970).

" See, e.g., Startz v. Cullen, 468 F.2d 560 (2d Cir. 1972); Lee v. Tahash, 352 F.2d 970, 972 (8th Cir. 1965). Lesser mistreatment, while not condoned, is not a constitutional violation. Cf. Cummins v. Ciccone, 317 F. Supp. 342 (W.D. Mo. 1970); State ex rel. Kopetka v. Young, 282 Minn. 529, 163 N.W.2d 49 (1968).

In Furman v. Georgia, 408 U.S. 238 (1972), there were intimations in the various concurrences that punishment that does not bear a rational relationship to a legitimate penological purpose, and was therefore unnecessary, should be held to violate the eighth amendment. See also Morris, The Future of Imprisonment: Toward a Punitive Philosophy, 72 Mrch. L. Rev. 1161, 1163 (1972) (citing authorities).

17 Ramsay v. Ciccone, 310 F. Supp. 600, 605 (W.D. Mo. (1970) (addendum). 
Application of the majority standard may often produce harsh results. A prison may use inferior medical procedures so long as they are not "shockingly" inferior, ${ }^{48}$ and the "most rudimentary" prison facilities are also permissible. ${ }^{49}$ Nevertheless, the majority standard does provide constitutional protection in certain limited circumstances: denying a prisoner access to the prison physician breaches the duty to provide care, as does the withholding of any prescribed treatment.50

Although the majority formulation of the prisoner's right to medical care is restrictive, it is not without a reasoned basis. Courts are generally unwilling to presume that prison officials treat their prisoners with intentional cruelty and are therefore unwilling to undertake the difficult task of reviewing medical decisions absent an independent demonstration of bad faith..$^{51}$ Further, the courts do not wish to become arbiters of patient-physician disputes, many of which may be frivolous. ${ }^{52}$ But, while this approach may be logical in view of a court's limited resources, it must be recognized that its major effect is to entrust the prisoner's constitutional right to medical care to the nearly unreviewable discretion of one or a few persons. ${ }^{53}$

${ }^{48}$ In re Robert Freeman, No. HC 1537 (San Diego Super. Ct. 1970), discussed in Goldin, supra note 25.

49 Lake v. Lee, 329 F. Supp. 196 (S.D. Ala. 1971).

so Tolbert v. Eyman, 434 F.2d 625 (9th Cir. 1970) (barring access of inmate to the prison druggist and thus to prescribed medication stated a claim upon which relief could be granted); Newman v. Alabama, 349 F. Supp. 278 (M.D. Ala. 1972), aff'd, 503 F.2d 1320 (5th Cir. 1974); Black v. Ciccone, 324 F. Supp. 129 (W.D. Mo. 1970) (requiring prisoner to work against physician's orders held to be unconstitutional). In Beckett v. Kearney, 247 F. Supp. 219 (N.D. Ga. 1965), aff'd, 363 F.2d 505 (5th Cir. 1966), allegations by a prisoner that he had been forced to do heavy work even though he had a prescription for a light work assignment were held to state a claim upon which relief could be granted; the question was mooted, however, when the officials reassigned the prisoner to light work. But see Carlisle v. Scott, 357 F. Supp. 1284 (N.D. Ill. 1973) (failure to provide prescribed diet held constitutionally permissible). See generally The EMERGing Rights, supra note 5, at 149.

${ }^{51}$ See, e.g., Skinner v. Spellman, 480 F.2d 539 (4th Cir. 1973); Oakes v. Wainwright, 430 F.2d 241 (5th Cir. 1970); Cates v. Ciccone, 422 F.2d 926 (8th Cir. 1970); Carswell v. Wainwright, 418 F.2d 231 (5th Cir. 1969); Coppinger v. Townsend, 398 F.2d 392 (9th Cir. 1970); cf. McCray v. Burrell, 516 F.2d 357 (4th Cir. 1975), petition for cert. filed, 44 U.S.L.W. 3053 (U.S. July 9, 1975) (No. 75-44). "[W] hen a prison guard acts in reliance on a good faith belief that what he is doing is constitutionally permissible, he is immune to damages as a consequence of his action even if it should be later established that his belief was ill-founded." Id. at 370 .

52 Tolbert v. Eyman, 434 F.2d 625 (9th Cir. 1970); United States ex rel. Hyde v. McGinnis, 429 F.2d 864 (2d Cir. 1970); McKinney v. California, 427 F.2d 160 (9th Cir. 1970); Chapman v. Gilligan, 2 PRI. L. RPTr. 420 (S.D. Ohio 1973); Davis v. Schmidt, 57 F.R.D. 37 (W.D. Wis. 1972).

${ }^{53}$ It has been suggested that the discretion problem could be eliminated by courtappointed medical review boards of doctors. It has also been suggested that prisoners should 


\section{B. The Minority Standard}

In Blanks v. Cunningham, ${ }^{54}$ the Court of Appeals for the Fourth Circuit apparently departed from the majority standard, substituting a right to "reasonable" medical care for the majority's right to "some" care. Although this standard has not yet been adopted by any other circuit, at least one district court outside the Fourth Circuit has employed the "reasonableness" language..$^{55}$

The most difficult question posed by the reasonableness standard is the definition of "reasonable," since courts that use the term rarely define it. In Ricketts $v$. Ciccone,$^{56}$ a district court outside the Fourth Circuit used a broad definition, stating that "prisons are legally obligated to provide available medical treatment of a type approved by recognized medical authority." ${ }^{7}$ But in Blakely $v$. Sheriff of Albemarle County, ${ }^{58}$ a district court in the Fourth Circuit applied a more limited definition. The court reaffirmed the principle that a prisoner is entitled to reasonable medical care, but enigmatically added that mistreatment must "shock the conscience" in order to reach constitutional dimensions. ${ }^{59}$ The court's apparent retreat to the majority position was perhaps an indication of its unwillingness to act as a medical review board.

Although it is impossible to predict which definition of "reasonable" will ultimately prevail, any expression of the minority standard should entitle prisoners to more than "some" medical care. More significantly, the yardstick for measuring unconstitutional medical care under the minority standard should be, not the culpability of prison officials, but rather the more objective criterion of

be permitted to be examined by privately retained physicians. Implementation of this proposal, however, might create prison disruptions and be prone to equal protection challenge. See, The. EMerang Rights, supra note 5, at 150.

st 409 F.2d 220, 221 (4th Cir. 1969). See also Edwards v. Duncan, 355 F.2d 993, 994 (4th Cir. 1966). The origin of the right to reasonable medical care is unclear. Blanks, the first case expressly to refer to that right, cites Hirons v. Director, Patuxent Institute, 351 F.2d 613 (4th Cir. 1965), as authority for the proposition that there is such a right. Nothing in Hirons supports this assertion, a fact which may suggest that the Fourth Circuit was not announcing a new standard, but was using new language to explain the old standard. A careful reading of Blanks, however, dispels this doubt. The plaintiff in Blanks alleged that the prison guards had forcibly prevented him from receiving treatment for his epileptic condition. If true, the allegations would have been clearly actionable under the majority standard as an intentional deprivation of treatment. The fact that the court chose to announce the standard of "reasonableness" in such an easy case suggests that it was conciously breaking new ground.

ss Ricketts v. Ciccone, 371 F. Supp. 1249, 1256 (W.D. Mo. 1974).

s6 317 F. Supp. 1249 (W.D. Mo. 1974).

57 Id. at 1256 .

5* 370 F. Supp. 814 (W.D. Va. 1974).

s9 Id. at 816 . 
the medical needs of the prisoner. Nevertheless, the right to receive reasonable care cannot be made absolute: the right to immediate care must be qualified both by the seriousness of the prisoner's need and by the burden that providing such care would place on the prison system. ${ }^{60}$

Finally, it must be noted that the vitality of the majority standard has not been seriously eroded by the evolution of a reasonableness standard. The majority standard has been applied in numerous recent cases, ${ }^{61}$ while the minority standard has rarely been applied outside the Fourth Circuit. ${ }^{62}$ The majority standard has thus remained the prevalent one, although other circuits may, under the notion of "evolving standards of decency,"63 eventually adopt the minority position.

\section{Toward a Proposed Standard of Care}

Although the minority standard of reasonable medical care has gained only a foothold in the law, the principle it represents is neither inappropriate nor is its use impracticable. Once it is recognized that a prisoner has a right to medical treatment, it is difficult to justify depriving that right of its essential meaning. The restrictive majority standard of care is not only inconsistent with the development of other constitutional guarantees, but is inherently illogical as well.

${ }^{60}$ Mills v. Oliver, 367 F. Supp. 77, 79 (E.D. Va. 1973).

${ }^{61}$ See, e.g., Startz v. Cullen, 468 F.2d 560 (2d Cir. 1972); Nettles v. Rundle, 453 F.2d 889 (3d Cir. 1971); Martinez v. Mancusi, 443 F.2d 921 (2d Cir. 1970); White v. Sullivan, 368 F. Supp. 292 (S.D. Ala. 1973); Carlisle v. Scott, 357 F. Supp. 1284 (N.D. Ill. 1973); Black v. Ciccone, 324 F. Supp. 129 (W.D. Mo. 1970); Ramsay v. Ciccone, 310 F. Supp. 600 (W.D. Mo. 1970).

${ }^{62}$ See, e.g., Ricketts v. Ciccone, 371 F. Supp. 1249, 1256 (W.D. Mo. 1974).

63 Gamble v. Estelle, No. 74-3727 (5th Cir., filed Aug. 4, 1975), might be a relevant example. In Gamble, the appellant had alleged that he had severely wrenched his back while working in prison but had never been permitted to have his injury examined by the prison physician. He further alleged that he was merely given a mild and ineffective pain pill and that he had been kept in solitary confinement for most of the months immediately subsequent to his injury. The Fifth Circuit held that the appellant had stated a valid cause of action entitling him to relief upon proper proof. Although the court could have easily reached this result under the majority standard by concluding that there had been a total deprivation of care alleged, the court expressly eschewed reliance on the majority standard cases, finding them not controlling. The court did not go so far as to adopt the minority "reasonableness" standard, but rather seemed to stake out some sort of middle ground, perhaps in line with its "standard of decency":

Moreover where the general medical services afforded by the State in its prisons are publicly known to be "woefully inadequate," the court must exercise the highest degree of care to make certain that a prisoner is not deprived of his federally secured right to medical care.

Cf. Smith v. Schneckloth, 414 F.2d 680 (9th Cir. 1969). 
The majority standard is illogical because it reads the eighth amendment to protect a right without substance: "some" care is often little better than no care. Moreover, the majority standard is a subjective one-a deprivation of treatment being a constitutional violation only if it is intentional or functionally equivalent to intentional-that often generates inconsistent results. For example, a constitutional violation is established when prison officials know of the prisoner's condition and ignore it; but if the same officials consider the same prisoner's case and erroneously conclude that no treatment is appropriate, then their behavior is constitutionally immune. ${ }^{64}$ Finally, even intentional deprivations must somehow be "shocking" to be constitutionally impermissible. The courts' apparent unwillingness to encourage frivolous claims and their reluctance to review the merits of medical decisions provide no logical justification for reading such an empty right into the eighth amendment.

In interpreting other constitutional guarantees, the courts have apparently not felt a similar need to harness the development of meaningful protections. For example, under the traditional view of the sixth amendment, a claim of violation of the right to counsel was actionable only if counsel's efforts were either nonexistent or so perfunctory as to render the proceeding a "farce and a mockery of justice." 65 The courts have recently abandoned this standard in favor of a malpractice or reasonableness standard, requiring that counsel's performance be of at least minimal competence. ${ }^{86}$ In deciding that the sixth amendment mandates effective counsel, the courts were aware that the right to counsel was of no real protective value if it could be satisfied by formal compliance. ${ }^{67}$

" United States ex rel. Ingram v. Montgomery Cty. Prison Bd., 369 F. Supp. 873, 874 (E.D. Pa. 1974).

${ }^{.5}$ See, e.g., Bell v. Alabama, 367 F.2d 243, 247 (5th Cir. 1966), cert. denied, 386 U.S. 916 (1967); Williams v. Beto, 354 F.2d 698, 704 (5th Cir. 1965); Nutt v. United States, 335 F.2d 817, 818 (10th Cir.), cert. denied, 379 U.S. 909 (1964); United States ex rel. Cooper v. Reincke, 333 F.2d 608, 613 (2d Cir.), cert. denied, 379 U.S. 909 (1964); Frand v. United States, 301 F.2d 102, 103 (10th Cir. 1962). See generally Finer, Ineffective Assistance of Counsel, 58 Cornell L. Rev. 1077, 1078 (1973).

"Tollett v. Henderson, 411 U.S. 258, 266, 268 (1973); Herring v. Estelle, 491 F.2d 125, 127-28 (5th Cir. 1974); Moore v. United States, 432 F.2d 730, 737 (3d Cir. 1970); Kott v. Green, 303 F. Supp. 821, 822 (N.D. Ohio 1968); New Jersey v. Anderson, 117 N.J. Super. 507, 519, 285 A.2d 234, 240 (App. Div. 1971). See generally Waltz, Inadequacy of Trial Defense Representation as a Ground for Post-Conviction Relief in Criminal Cases, 59 Nw. U.L. REv. 289,293 (1964).

${ }^{67}$ Id. It can be argued that the analogy between the rights to effective medical care and to effective counsel is weak because the latter is based on an express constitutional right, whereas the former is derivative. Nevertheless, the analogy may still be persuasive to the extent that it indicates the courts' willingness to protect a constitutional right by establishing 
Since the right to medical care is empty without an assurance of adequacy, the lesson of sixth amendment development should be applied to give content to the constitutional right to medical care. Moreover, importing an adequacy standard into the right to medical care would not require a court to review medical decisions; rather than second-guessing the physician's choice of treatment, the court would simply ask whether the treatment prescribed and provided was medically indicated under the circumstances. The courts would not defer to the prison doctor's assertion that he had provided "some" treatment, but would defer to a showing that a private physician might reasonably have prescribed the same treatment.

The adequacy of care standard also comports with the eighth amendment principle underlying the right to in-prison medical care, that the punishment imposed on the prisoner should not be increased by personal medical problems. If a physician prescribes or renders "some" treatment for a prisoner, but some other treatment would normally have been prescribed or provided as a matter of course by a privately retained physician, then, assuming the disparity in treatment was not inconsequential, it is difficult to resist the inference that the maltreatment was due solely to the patient's status as a prisoner and hence presumptively unconstitutional. If, on the other hand, the treatment prescribed or administered might well have been dispensed to a non-prisoner patient, it cannot be viewed as punishment.

The right to medical care under the proposed standard, as under the "reasonableness" standard, ${ }^{68}$ cannot be unnecessarily qualified. It would first be necessary to determine whether the prisoner had received generally accepted medical treatment and, if not, whether the deprivation was not inconsequential. If the prisoner did not receive adequate care, a prima facie case of constitutional violation would be established which the government could attempt to rebut by arguing that legitimate government interests, such as prison security, justified withholding the care. On a showing of inadequate and hence impermissible treatment, the prisoner would be entitled to damages ${ }^{69}$ or injunctive relief, absent a showing of a legitimate countervailing government interest.

a standard that requires more than formal compliance. Cf. Donaldson v. O'Connor, $95 \mathrm{~S}$. Ct. 2486 (1975) (concerning the rights of civilly commited mental patients to therapeutic treatment).

88 See text and note at note 60 supra.

68 Various cases stated that a prisoner may receive money damages for a breach of his constitutional right to medical care. See, e.g., Ramsay v. Ciccone, 310 F. Supp. 600, 605 (W.D. Mo. 1970) (addendum). Yet it is difficult to surmise how these damages are to be 


\section{The Right to Rehabilitative Treatment}

Once a right to receive remedial medical treatment is established, there is likely to be an attempt to extend the scope of that right to guarantee the prisoner affirmative, long-term rehabilitative medical treatment. Because the leading cases establishing a right to rehabilitative treatment have involved incarcerated juveniles ${ }^{70}$ and involuntarily committed mental patients, ${ }^{71}$ the argument that there is a comparable right for the prisoner is likely to proceed by analogy.

Where the right to rehabilitative treatment is recognized, it derives from fundamental notions of due process: simply put, when a person is committed to an institution for the express purpose of rehabilitation, he is entitled to treatment designed for his rehabilitation. ${ }^{72} \mathrm{~A}$ person confined solely for the purpose of rehabilitation is deprived of his liberty without due process of law if he does not receive rehabilitative treatment. Indeed, some courts have referred to rehabilitation as the quid pro quo that the government owes in return for the individual's loss of liberty. ${ }^{73}$ This principle may, however, have been weakened by the Supreme Court's recent rejection, in Donaldson v. O'Connor, ${ }^{74}$ of the Court of Appeals' reliance on such a broadly based constitutional right and Chief Justice Burger's explicit rejection of the "quid pro quo" rationale in a concurring opinion. ${ }^{75}$

Whatever the right to social rehabilitation of juvenile delinquents or mental patients under the due process rationale, it is clear that, at least at the present time, prisoners have no analogous right. When a convicted criminal is sentenced to jail or prison, his incarceration serves the purposes of punishment, specific and general deterrence, and isolation from the community, as well as rehabilitation. ${ }^{76}$ Thus the courts have sanctioned prison systems lacking reha-

computed. Although tort standards probably would not be used because the courts view the tort and constitutional actions as distinct, it is unclear what standard should be used instead.

7 See, e.g., Nelson v. Heyne, 491 F.2d 352, 358-59 (7th Cir. 1974); Morales v. Turman, 364 F. Supp. 166, 175 (E.D. Tex. 1973); Martarella v. Kelley, 349 F. Supp. 575, 585 (S.D.N.Y. 1972).

"Welsch v. Likins, 373 F. Supp. 487 (D. Minn. 1974) (civilly committed mentally retarded have a right to treatment); Stachulak v. Coughlin, 364 F. Supp. 686 (N.D. Ill. 1973) (right to treatment for patients civilly committed involuntarily); cf. Donaldson v. O'Connor, 493 F.2d 507 (5th Cir. 1974), aff'd on different grounds, 95 S. Ct. 2486 (1975).

2 See id. and note 70 supra.

is Donaldson v. O'Connor, 493 F.2d 507, 524 (5th Cir. 1974), aff'd on different grounds, 95 S. Ct. 2486 (1975).

" 95 S. Ct. 2486 (1975).

${ }^{35} \mathrm{Id}$. at 2499.

36 Cf. Zimring, Current Aspects of Penology: Threat of Punishment as an Instrument of 
bilitative programs and facilities. ${ }^{77}$

While prisoners currently have no right to social rehabilitation, they may have a right to long-term medical rehabilitation. In the case of treatment for narcotics addiction, however, medical treatment, which may be constitutionally required, and vocationalpsychological therapy, which is not so required, logically coalesce..$^{78}$ It is difficult to locate the point at which treatment is no longer designed to combat the psychological roots of the disease, but rather is intended to rehabilitate. Therefore, given that prisoners are constitutionally entitled to medical care and that one of the avowed purposes of penal incarceration is rehabilitation, a combination of logic and societal interests in decency and "curing" the root cause of individual criminality may force a general re-examination of the rehabilitation doctrine in the prison context and a specific recognition of a right to long-term medical rehabilitation.

\section{The Disease of Addiction and its Various Cures}

\section{A. The Disease of Addiction}

The command of the cruel and unusual punishment clause of the eighth amendment is at once positive and negative. The amendment not only prohibits the infliction of inhumane treatment upon prisoners, but also requires attention to the medical needs of prisoners because a failure to treat may itself constitute inhumane treatment. Forcing a prisoner to withdraw from a dependency on narcotic drugs without benefit of detoxificants could be viewed as a violation of either the positive or negative commands of the eighth amendment: the pain caused by abrupt withdrawal could be viewed as inhumane treatment in itself, or the "treatment" by way of abrupt withdrawal could be viewed as a breach of the duty to provide medical care. The latter possibility will form the focus of the remainder of this comment.

Crime Control, 118 Proc. Am. PHIL. Soc. 231 (June 1974); Rudolph v. Alabama, 375 U.S. 889, 891 (1963) (Goldberg; J., dissenting); Comment, Appellate Review of Primary Sentencing Decisions, A Connecticut Case Study, 69 YaLE L.J. 1453, 1455 (1960). But see Morris, The Future of Imprisonment: Toward a Punitive Philosophy, 72 Mrch. L. REv. 1161 (1974), arguing that rehabilitation is not and should not be the purpose of imprisonment.

7 See, e.g., Holt v. Sarver, 309 F. Supp. 362, 379 (E.D. Ark. 1970); Wilson v. Kelley, 294 F. Supp. 1005, 1012-13 (N.D. Ga. 1968).

${ }^{78}$ United States v. Fitzgerald, 466 F.2d 377 (D.C. Cir. 1972). In Fitzgerald the court dismissed as unwarranted on the record a claim that rehabilitation was unconstitutionally denied, but noted that federal prisoners can receive care and treatment for narcotics addiction "just as they can for any other personal affiction" under 18 U.S.C. $\S 4042$ (1970). 466 F.2d at 380 . 
In Robinson $v$. California,$^{79}$ the issue before the Court was whether criminally punishing a person simply for being an addict violated the eighth amendment. The Court quoted with approval its language from Linder $v$. United States that addicts "are diseased and proper subjects for [medical] treatment," 80 and held that the status of being diseased could not form the predicate for criminal liability. Although the Court eased its path to this conclusion by noting that addiction may be involuntarily induced, ${ }^{81}$ this language limited neither the scope of the precise holding nor the definition of a "disease" for eighth amendment purposes to illnesses that are not voluntarily contracted. The Court observed that the status of having venereal disease, which is ordinarily contracted through a voluntary act, also could not form the predicate for criminal liability. ${ }^{82}$

Treatment of the symptoms of addiction is not constitutionally mandated simply because addiction may properly be labelled a "disease." But when a prison official chooses to eliminate one of the aspects of addiction-physiological dependence on the drug-by denying the prisoner access to the drug, the official has, in effect, chosen to attempt to cure one of the prisoner's symptoms. The "cure" by an abrupt, "cold turkey" withdrawal has painful collateral effects, ${ }^{83}$ although it is rarely fatal. ${ }^{84}$ If, as will be argued below, ${ }^{85}$ there is an effective means of treating physiological dependence other than by abrupt withdrawal-such as methadone detoxification-without the same painful effects or other medical complications, it would be difficult to discern any reason other than retribution for denying a drug-dependent prisoner such treatment.

The magnitude of this problem should not be minimized. It has been estimated that there were between 250,000 and 559,000 narcotics addicts in the United States in $1971 .{ }^{86}$ It has also been estimated

370 U.S. 660 (1962).

so Id. at $667 \mathrm{n} .8$.

${ }^{81} \mathrm{Id}$. at 667.

2 Id. at 666-67.

${ }^{83}$ Symptoms include running of the eyes and nose, difficulty in swallowing, severe gastro-intestinal cramps, diarrhea, frequent vomiting, loss of appetite, dehydration, generalized muscle cramps, copious sweating, hot and cold flashes and chills, increased blood pressure, and insomnia. AMA Council on Mental Health, Treatment of Morphine-Type Dependence by Withdrawal Methods, 219 J.A.M.A. 1611-12 (1972); Wenk, Methadone Detoxification in Prison: A Case Study in Philadelphia, in Discrimination ANd the Addict 209, 211-14 (L. Simmons \& M. Gold eds. 1974).

Letter from E. Senay, M. D., Director, Illinois Drug Abuse Program (July 29, 1974).

*s See text and notes at notes 94-103 supra.

st R. GoldFARB, supra note 1 , at 114. 
that 200,000 addicts spend some time in jail or prison annually ${ }^{87}$ Although these figures are at best rough approximations, they indicate that there are a substantial number of addicts in this country who may have to face the prospect of being "cured" of their physiological dependence by forced abrupt withdrawal in prison or jail. ${ }^{88}$

\section{B. Methadone: The Medically Indicated Treatment}

Methadone, a synthetic narcotic, has recently come into widespread use as a painless, short-term "cure" for physical drug dependence and as a long-term narcotic substitute in supervised programs. ${ }^{89}$ By 1973 , approximately 73,000 persons were participating in regulated ${ }^{90}$ long-term methadone maintenance programs ${ }^{91}$ throughout the nation, ${ }^{92}$ while countless others had gone through curative detoxification programs.

The first step in the typical short-term in-prison methadone detoxification program is a medical examination at the time of entry. Detoxification treatment, consisting of a series of gradually decreasing doses of methadone over a one to three week period is offered to "hard" drug addicts and to methadone-maintained prisoners. The treatment substantially cures the addict of his physiological drug dependency without producing the suffering caused by abrupt withdrawal. ${ }^{93}$

There is virtual unanimity among physicians and students of the criminal justice system that abrupt withdrawal is an improper means of "curing" drug addiction. Although it will substantially eliminate physiological drug dependency, abrupt withdrawal has no other therapeutic value. ${ }^{94}$ Since detoxification can also substantially

${ }^{87}$ Id. at 119.

s In mid-1972 between 10 and 25 percent of the nation's local and county jails had addiction treatment programs. Only a few of these programs involved methadone detoxification. Criminal Justice Information \& Statistical Service, Law Enforcement Assistance Administration, U.S. Dep't of Justice, Survey of Inmates IN Local JaILs (1974) (1972 Advance Report estimating that 25 percent of jails have drug treatment programs); R. GoldFARB, supra note 1, at 86 (estimating that 9.1 percent of jails have treatment facilities).

${ }^{89}$ See generally Dole, Detoxification of Sick Addicts in Prisons, 220 J.A.M.A. 366 (1972).

Al methadone use is regulated; 21 C.F.R. $\$ 310.505$ (1974). See also 21 C.F.R. $\$ 3.77$ (1974).

81 For a discussion of the components of a long-term methadone maintenance program, see AMA Council on Mental Health, Oral Methadone Maintenance Techniques in the Management of Morphine-Type Dependency, 219 J.A.M.A. 1618 (Mar. 20, 1972).

22 Epstein, Methadone, The Forlorn Hope, 36 The PuB. InTERest 3 (1974).

${ }^{93}$ Dole, Detoxification of Sick Addicts in Prisons, 220 J.A.M.A. 366 (1972). See also R. GoldfarB, supra note 1 , at 140-42. There is considerable variety in existing methadone detoxification programs in municipal jails. Id. at 144-46.

'4 See, e.g., Jaffe, Zaks, \& Washington, Experience with the Use of Methadone in a 
eliminate the physical dependency without producing the harsh effects of abrupt withdrawal or other side effects, the failure to provide a detoxificant would seem unjustifiable. ${ }^{95}$

Methadone, moreover, is generally considered to be the most effective detoxificant..$^{96}$ For example, Dr. Edward Senay, Director of the Illinois Drug Abuse Program, concludes that ". . . because of its long duration of action and because of its effectiveness when given orally . . . the substitution of methadone is universally recommended and practiced." "97 The United States Public Health Service considers methadone to be the most satisfactory method of "curing" physiological drug dependence. ${ }^{98}$ The American Medical Association also concludes that abrupt withdrawal is "inhuman, unnecessary, and distinctly contraindicated, even if the patient is in jail.",99

Although valium and other tranquilizers are occasionally used to temper the harshness of abrupt withdrawal, such treatment is widely regarded as inadequate and ineffective. ${ }^{100}$ Tranquilizers, like abrupt withdrawal, lack independent therapeutic value ${ }^{101}$ and merely blur, to a certain extent, the patient's perception of the painful side effects of the withdrawal. While tranquilizers are considered minimally effective in cases of light drug habits, ${ }^{102}$ there is

Multi-Modality Program for the Treatment of Narcotic Users, 4 INT'L J. ADDictions 481, 487 (1969).

${ }^{25}$ In fact, the prognosis for completely eliminating physiological drug dependency after one treatment-whether it be by abrupt withdrawal or by methadone detoxification -is poor except for an emotionally normal individual medically addicted in the course of treatment for painful injury or illness. The normal recidivism rate is high. 7 Traumatic Medicine and SURGERY FOR THE ATTORNEY 538, 539 (P. Cantor ed. 1962). There are, however, many other diseases, such as malaria, that also require prolonged treatment.

" AMA Council on Mental Health, Narcotics and Medical Practice, 202 J.A.M.A. 209, 211 (1967); R. GoldfarB, supra note 1 , at 149; Statement of N. Zinberg, M.D., Associate Professor of Psychiatry, Harvard Medical School, March 7, 1975, on file at The University of Chicago Law Review.

"Statement of E. Senay, M.D., Director, Illinois Drug Abuse Program, Illinois Dep't of Mental Health \& Developmental Disabilities, March 13, 1975, on file at The University of Chicago Law Review.

is Nat'l Clearinghouse for Drug Abuse Information: Methadone: The Drug and iTs Therapeutic Uses in the Treatment of Addiction 7 (1974).

" AMA Council on Mentaz Health, supra note 83, at 1611. See also AMA Committee on Alcoholism and Drug Dependency, Narcotics and Medical Practice, 218 J.A.M.A. 578 (1971).

Statement of J. Jackman, M.D., Director, Lanakila Mental Health Clinic, Kalihi Palama Community Mental Health Center, Honolulu, Hawaii, March 6, 1975, on file at The University of Chicago Law Review; R. GoldFaRB, supra note 1, at 136. But see id. at 148-49.

10t Statement of N. Zinberg, supra note 96; R. GoldFARB, supra note 1 at 136.

${ }^{102}$ Cf. In re Robert Freeman, No. HC 1537 (San Diego Super. Ct., 1970), discussed in Goldin, supra note 25. 
general agreement that methadone is the only appropriate treatment in all other cases. ${ }^{103}$

Methadone is not only used as a short-term treatment to cure physiological dependency but is also used in long-term maintenance programs, as a narcotics surrogate in conjunction with rehabilitative services. Unlike the use of methadone for detoxification, the use of methadone as a long-term maintenance treatment has generated considerable controversy, both in the medical profession and in the society at large.

The proponents of long-term use assert that methadonemaintained persons are less likely to engage in criminal and other anti-social behavior, ${ }^{104}$ are more likely to be employable, ${ }^{105}$ and are more likely to reach and maintain a drug-free status ${ }^{100}$ than are ordinary heroin addicts. Critics of maintenance, on the other hand, observe that maintained patients are still drug-dependent and thus have not achieved abstinence-the "only legitimate objective" of a drug treatment program. ${ }^{107}$ Critics have also asserted that the patients used in pilot maintenance programs did not represent an unbiased sample of drug addicts ${ }^{108}$ or that maintenance programs are a covert means of "enslaving" members of racial minorities. ${ }^{109}$

${ }^{103}$ Jackson v. Hendrick, No. 71-2447 (Ct. C.P., Philadelphia, 1972), discussed in Wenk, Methadone Detoxification in Prison: A Case Study in Philadelphia, in Discriminatron and THE ADdict 209 (L. Simmons \& M. Gold eds. 1974); Jaffe, Washington \& Zaks, Experience with the Use of Methadone in a Multi-Modality Program for the Treatment of Narcotic Users, 4 INT'L J. AdDictions 481, 486 (1969).

104 Nat'l Criminal Justice Information \& Statistics Service, Law Enforcement Assistance Administration, U.S. Dep't of Justice, Heroin Use and Crime in a Methadone Maintenance Program (1973); Cushman, Methadone Maintenance Treatment of Narcotic Addiction, 72 N.Y. ST. J. Med. 1752 (1972); DuPont \& Katon, Development of a HeroinAddiction Treatment Program: Effect on Urban Crime, 216 J.A.M.A. 1320 (1971); Jaffe, Washington \& Zaks, Experience with the Use of Methadone in a Multi-Modality Program for the Treatment of Narcotic Users, 4 INT'L J. Addictions 481 (1969); Senay, Jaffe, Chappel \& Renault, Illinois Drug Abuse Program-Five Year Results, in Proceedings of the Fifth annual National Conference on Methadone Treatment 1437 (1973).

105 Jaffe, Washington \& Zaks, Experience with the Use of Methadone in a MultiModality Program for the Treatment of Narcotic Users, 4 INT'L J. Addicrions 481, 486 (1969); Senay, Jaffe, Chappel, \& Renault, Illinois Drug Abuse Program-Five Year Results, in Proceedings of the Fifth annual National Conference on Methadone Treatment 1437 (1973).

${ }^{108}$ Senay \& Renault, Treatment Methods for Heroin Addicts: A Review, 3 J. Psych. Drugs 47 (1971).

107 Nat'l Clearinghouse for Drug abuse Information, Methadone: The Drug and its Therapeutic Uses in the Treatment of Addiction 13 (1974) (quoting Expert Committee on Drug Dependence, World Health Organization).

${ }^{103}$ AMA Methadone Maintenance Evaluation Committee, Progress Report of Evaluation of Methadone Maintenance Treatment, 206 J.A.M.A. 2712 (1968); Epstein, supra note 92.

109 Nat'l Clearinghouse for Drug Abuse Information, supra note 107, at 14. 
More importantly, the medical community is as yet unwilling to give its wholehearted approval to long-term methadone maintenance. ${ }^{110}$ Although the authorities disagree about whether longterm maintenance produces harmful side effects, it seems clear that further study is required before a definitive conclusion may be reached. ${ }^{111}$

The controversy over methadone maintenance is only partially relevant in the present context. When an addict or methadonemaintained person is incarcerated, the issue that generally arises is whether he has a right to "curative" short-term detoxification rather than long-term methadone maintenance. Prisons are only required by the eighth and fourteenth amendments to provide medical care to prisoners; they are not obliged to provide rehabilitative services. In certain cases, however, such as that of the methadonemaintained pretrial detainee, the right to long-term maintenance will be important.

Thus, although the appropriateness of long-term methadone maintenance is the source of medical controversy, short-term detoxification through methadone is currently the accepted "cure" for physiological drug dependency. Whether the Constitution requires that either form of treatment be made available, where appropriate, to addicts in jails or prisons is a more difficult question.

\section{The Drug-Dependent Prisoner's Constitutional Rights to Medical Care}

Whether a prisoner or pretrial detainee has a constitutional right to short-term methadone detoxification or comparable treatment is largely dependent on which standard of care is applied. It is unlikely that prisoners would be held to have such a right under the majority standard, but the minority standard, especially as expressed above in the proposed standard, would probably accord a right to short-term detoxification.

\section{A. The Convicted Prisoner}

1. The Majority Standard. Under the majority standard, ${ }^{112}$

10 Compare National Institute of Law Enforcement \& Criminal Justice, Methadone Treatment Manual 19 (1973), with Kreek, Medical Safety \& Side Effects of Methadone in Talerant Individuals, 223 J.A.M.A. 665 (1973), and Kreek, Physiological Implications of Methadone Treatment, in Procedures of the Fifth Annual National Conference on MethaDONE TREATMENT (1973).

"II Senay \& Renault, supra note 106.

112 See text and notes at notes 44-53 supra. 
whether it would be unconstitutional to deny methadone detoxification or comparable treatment to a drug-dependent prisoner would depend on the circumstances surrounding the denial. If the prison official knew of the prisoner's addiction and intentionally failed to provide any treatment, then the deprivation would be unconstitutional; the violation would occur, however, not because methadone was denied but because "some" treatment had not been provided. If, on the other hand, the official considered the prisoner's condition and decided that abrupt withdrawal was the proper treatment, then, despite the prisoner's evident need for treatment, there would be no constitutional violation. ${ }^{13}$

Thus it appears that a drug-dependent prisoner would not presently be entitled to short-term methadone detoxification under the majority standard. It is possible, however, that the courts adopting the majority standard will eventually recognize a right to short-term detoxification. As evidence of the medical acceptability of methadone becomes even stronger, they may determine that forcing a prisoner to go through abrupt withdrawal constitutes "no" rather than "some" treatment, thereby violating the eighth amendment. Decisions in two local courts indicate that this possibility may not be wholly unrealistic. In In re Robert Freeman ${ }^{114}$ and Jackson $v$. Hendrick ${ }^{115}$ the courts suggested that prison officials may be under a duty to provide detoxification treatment if the treatment otherwise provided to a drug-dependent prisoner is tantamount to "no" treatment at all.

Interesting questions arise under the majority standard when methadone has been prescribed for a drug-dependent prisoner and for some reason the prisoner is denied access to it. If the prison physician himself prescribed the treatment, the subsequent deprivation by prison authorities would clearly violate the eighth amendment because a prisoner is entitled to the treatment prescribed for him. If, however, the prisoner is a participant in a registered methadone maintenance program when he enters the jail or prison, a determination by the prison official or physician that abrupt withdrawal is the proper cure would not be actionable. In that case, there would not be an intentional deprivation of treatment for eighth amendment purposes, but rather a medical decision concerning proper treatment. This decision would be subject to constitu-

${ }^{113}$ United States ex rel. Ingram v. Montgomery Cty. Prison Bd., 369 F. Supp. 873, 87677 (E.D. Pa. 1974).

11 In re Robert Freeman, No. HC 1537 (San Diego Super. Ct., 1970).

${ }^{115}$ Jackson v. Hendrick, No. 71-2437 (Ct. C.P., Philadelphia, 1972). 
tional scrutiny only if methadone detoxification were such a wellestablished and uniformly accepted treatment that the failure to detoxify gradually could be characterized as a complete deprivation of treatment that would "shock the conscience."

2. The Minority Standard. Under the proposed formulation of the minority "reasonable" care standard-that is, the prisoner has a prima facie right to adequate medical care as determined by objective medical standards ${ }^{16}$ - the drug-dependent prisoner would probably have a right to short-term methadone detoxification. Three factors dictate this result: methadone is the generally accepted treatment for physical drug dependency; the suffering caused by abrupt withdrawal, even if tempered by tranquilizers, is severe; and there is no readily apparent government interest that would justify withholding the treatment.

First, it has already been shown that short-term methadone detoxification is the medically indicated method of eliminating physical drug dependency. ${ }^{117}$ The reasoning behind this conclusion is dual: methadone painlessly eliminates physiological drug dependence without causing adverse side effects, while the painful "treatment" by way of abrupt withdrawal lacks independent therapeutic value. It bears noting, however, that prison officials will not be permanently locked-in to prescribing methadone under the minority standard. The development of more effective medically accepted treatments will terminate the obligation to prescribe methadone.

Second, it has been noted that the minority/proposed standard implicitly incorporates a de minimis exception. For example, common sense would suggest that a claim that buffered aspirin rather than ordinary aspirin was the medically indicated treatment should lack constitutional stature. There is no reason to infer a retributive intent from the choice of treatments in such a case, nor will the deprivation be apt to produce sufficient suffering to warrant judicial intervention. Although it is impossible to draw a clear line between severe and insignificant medical deprivations, the distinction is readily apparent in the case of drug addiction: except in the case of a "light" drug habit, a failure to provide methadone detoxification or comparable treatment will produce severe suffering. Yet a determination by the prison physician that a prisoner's habit was too slight to warrant methadone should be accorded considerable weight, absent a showing of bad faith. 
Finally, there is no strong, apparent government interest that would justify withholding methadone detoxification from drugdependent prisoners. The first argument that could be put forth in an attempt to justify withholding it is that prison security and morale would be impaired by the presence of the program and the drug itself in the prison. The significance of the concern with prison morale is, however, overstated. Although prisoners might be resentful if fellow prisoners were permitted to indulge their drug habits permanently through long-term methadone maintenance, they would probably not resent the dispensing of methadone over a short period to eliminate their fellow prisoners' suffering. Indeed, a policy of refusing to provide short-term detoxification might have the opposite effect, damaging morale and producing additional resentment against the prison and the society that refused to alleviate such suffering.

Similarly, the concern for prison security is exaggerated. Although there is a possibility that an in-prison detoxification program could be abused and thus serve to aggravate rather than mollify the prison drug problem, this possibility is not sufficiently likely to justify a wholesale policy of compelling abrupt withdrawal for all drug-dependent prisoners. One court has stated that, on principle, only those individuals whose behavior demonstrates that they may not be trusted may be excluded from a prison drug treatment program on security grounds. ${ }^{118}$ More importantly, actual prison experience indicates that security problems are not likely to occur ${ }^{119}$ and that any problems that do arise are easily combatted by dispensing the methadone under controlled conditions, such as in the prison hospital. ${ }^{120}$

A second possible justification for withholding methadone is the expense involved in furnishing it. But expense may not always be an adequate justification for withholding treatment: where the prisoner has a significant need for treatment and the marginal expense of the superior treatment is not unreasonably prohibitive, the prison may be required to provide the better and more expensive treatment. ${ }^{121}$ Although it is difficult to balance necessity and ex-

118 Sawyer v. Sigler, 320 F. Supp. 690, 694, 695-96 (N.D. Neb. 1970).

11 See Dole, Detoxification of Sick Addicts in Prisons, 220 J.A.M.A. 366 (1972).

120 Cudnik v. Kreiger, 3 PrI. L. RPTR. 221 (E.D. Ohio 1974).

121 Gates v. Collier, 501 F.2d 1291, 1303, 1320 (5th Cir. 1974); Pisadano v. New York, 8 App. Div. 2d 335, 188 N.Y.S.2d 35 (1959) (court held in tort action that the moderate expense of a particular curative treatment generally will not justify giving a less expensive, but ineffective treatment). See also Rhem v. Malcolm, 371 F. Supp. 594, 626-27 (S.D.N.Y.), aff'd, 507 F.2d 333 (2d Cir. 1974) (court ordered structural changes in prison facility to provide space necessary for prisoners to engage in the "right to reasonable physical exercise"). 
pense in the abstract, methadone is a relatively inexpensive synthetic substance, the purchase and distribution of which should not unduly tax the financial resources of the prison system.

Finally, there is the widely held belief that any form of legalized dependency on drugs is morally offensive, ${ }^{122}$ a belief that generates moral contempt for any use of methadone in prison or jail. If they are inclined to think this way, prison officials may regard the pain of abrupt withdrawal as the addict's just desert for his moral infirmity. ${ }^{123}$

The moral justification for withholding treatment, however, is patently unreasonable. First, it proves too much: one could justify withholding treatment for any medical problem, such as syphillis or slashed wrists, that was in some way self-inflicted on the theory that the prisoner was simply suffering the consequences of his own immorality. Second, it is not clear why the moral standards of prison officials, or their perception of societal standards, should have any bearing on the prisoner's constitutional right to medical care. While one of the purported purposes of incarceration is to teach prisoners to abide by societal standards, this teaching process should be confined to social, vocational, or psychological rehabilitation programs. The choice of treatment for physiological drug dependency is a medical rather than a rehabilitative decision. The moral argument would seek to justify imposing medically unnecessary suffering on a prisoner as an exemplary punishment for being a drug addict. The argument thus unwittingly concedes that abrupt withdrawal is imposed solely for retributive purposes and hence may be unconstitutional.

Thus, under the proposed formulation of the minority standard, methadone-maintained prisoners and heroin addicts would apparently have the right to short-term detoxification or comparable treatment, absent special circumstances that justify withholding treatment. Prison officials would not, however, be required to provide convicted drug-dependent prisoners with longterm methadone maintenance because the officials are not under a duty to provide rehabilitative treatment and because there is still

${ }^{122}$ Note, Methadone Maintenance for Heroin Addicts, 78 Yale L.J. 1175, 1185 (1969).

123 The Narcotic Addict Rehabilitation Act, which was amended to permit methadone use, would suggest that, as a matter of federal policy, use of synthetic narcotics is not morally offensive. See text and notes at notes 34-39 supra. It should also be noted that the Food and Drug Administration implicitly sanctions, by way of regulation, all methadone maintenance programs. See note 90 supra. 
substantial doubt as to whether long-term maintenance is a medically acceptable treatment. ${ }^{224}$

\section{B. The Pretrial Detainee}

The question of whether pretrial detainees have a right to shortterm methadone detoxification or long-term maintenance is distinguishable from the question examined above-whether convicted prisoners have those same rights. As an unconvicted person held only under probable cause, the pretrial detainee may be treated as a prisoner only to the extent necessary to ensure his presence at trial. ${ }^{125}$ Conditions for pretrial detention of persons charged with a crime must, therefore, not only be equal to, but in some cases must exceed, those provided for convicted prisoners. ${ }^{126}$

Since pretrial detainees have greater in-prison rights than convicted prisoners, it follows that they would possess any rights to medical treatment-and therefore to methadone treatment-that convicted prisoners would have. ${ }^{127}$ In fact, pretrial detainees are protected not against cruel and unusual punishment, but rather against any punishment at all:128 due process requires that a judicial determination of guilt precede punishment. ${ }^{129}$ Thus, in Jones $v$. Wittenberg, ${ }^{130}$ the court held that causing suffering by summarily denying pretrial detainees effective treatment was unconstitutional punishment-even though a reasoned denial might not have breached the constitutional duty to provide medical care.

While it is clear that, at least in the jurisdictions employing the minority standard, the pretrial detainee would have the right to short-term methadone detoxification, the more significant question is whether the pretrial detainee also has a right to methadone maintenance in circumstances in which it need not be provided to the convicted prisoner. First, as a federal district court recognized in Cudnik v. Kreiger, ${ }^{131}$ a pretrial detainee who is a participant in a

121 See text and notes at notes 104-11 supra.

${ }^{125}$ Inmates of Milwaukee Cty. Jail v. Peterson, 353 F. Supp. 1157, 1160, 1166 (E.D. Wis. 1973); Collins v. Schoonfield, 344 F. Supp. 257 (D. Md. 1972); Seale v. Manson, 326 F. Supp. 1375, 1379 (D. Conn. 1971).

${ }^{128}$ Hamilton v. Love, 328 F. Supp. 1182, 1191 (E.D. Ark. 1971). But see Kersh v. Bounds, 501 F.2d 585 (4th Cir. 1974).

${ }^{127}$ Collins v. Schoonfield, 344 F. Supp. 257 (D. Md. 1972).

${ }^{128}$ Rhem v. Malcolm, 507 F.2d 333 (2d Cir. 1974).

${ }^{129}$ Hamilton v. Love, 328 F. Supp. 1182, 1191 (E.D. Ark. 1971).

130323 F. Supp. 93 (N.D. Ohio 1971).

1313 PRI. L. RPTR. 221 (E.D. Ohio 1974). California has provided by statute that a detainee who is a participant in a methadone maintenance program when incarcerated has a right to continue in the program until he is convicted. CAL. HEALTH \& SAFETY Code $\$ 11222$ (West Supp. 1974). 
registered long-term maintenance program has a strong claim to continued maintenance while awaiting trial, since it is not necessary to discontinue his treatment in order to ensure his presence at trial.

It is more difficult to determine whether an addict who is not participating in a registered program can lay claim to methadone maintenance while he is awaiting trial. Even though he is technically a free person, the prison cannot be obliged to allow him to commit a felony in prison facilities by continuing his narcotics habit. Assuming that the prison officials decide to wean the addict of his physiological narcotics dependency, the question is whether they must substitute methadone for his habit or may "cure" him consonant with applicable eighth amendment standards.

No authority controls this case. It could be argued that prison officials should not be obliged to substitute one disease for another by substituting methadone for narcotics. But long-term maintenance programs are premised on the conviction that maintenance is, in fact, curative treatment designed to help eliminate the more subtle, deeper causes of the disease. The question is a close one that should eventually be decided on the basis of a medical evaluation of maintenance treatment. In any event, even if a court were to decide that prison authorities were free either to "cure" or maintain the pretrial detainee, it should scrutinize the choice of treatment with extra care. The court should be most reluctant to sanction the use of the abrupt withdrawal "treatment," however, because the addict detainee, who is technically a free citizen, could have arranged for the treatment of his choice had he not been kept under custody to ensure his presence at trial.

\section{Conclusion}

In the final analysis, it is difficult to assert confidently that a drug-dependent prisoner or pretrial detainee either does or does not have a right to methadone detoxification or maintenance. Since litigation has not yet conclusively tested the application of the prisoner's common law, statutory, or constitutional rights to medical care in the case of the drug-dependent prisoner, any conclusion is at best reasoned speculation. Yet one theme unites these various strands of analysis: if short-term methadone detoxification is the proper medical "cure" for physiological drug dependency, it is difficult to justify withholding it from a prisoner whose drug dependency is to be eliminated. Under the common law and the various state and federal statutes, forcing a prisoner to withdraw from narcotics abruptly, even if his pain is eased to a certain extent by tranquilizers, would be actionable if withholding methadone were considered 
medical malpractice. Similarly, a drug-dependent prisoner or detainee could compel the prescription of short-term methadone detoxification or comparable treatment under the proposed formulation of the minority standard of constitutionally mandated medical care if it were the generally accepted medical treatment. There might not be a right to such treatment under the majority standard, however, because the prison officials' obligation is discharged by providing "some," though not necessarily "adequate," medical treatment. Yet it is possible that a right to methadone detoxification will eventually be recognized by equating the failure to provide detoxification treatment with a total deprivation of care. Finally, because there is no constitutional right to social rehabilitation for prisoners and because the use of methadone for long-term maintenance has not yet gained general medical acceptance, only pretrial detainees who are already participating in regulated maintenance programs when incarcerated would have any likelihood of success in demanding long-term methadone maintenance while in jail. 